\title{
THE INEFFECTIVENESS OF ENTREPRENEURSHIP POLICY: IS POLICY \\ FORMULATION TO BLAME?
}

\begin{abstract}
Entrepreneurship policy has been criticised for its lack of effectiveness. Some scholars, such as Scott Shane in this journal, have argued that it is 'bad' public policy. But this simply begs the question why the legislative process should generate bad policy? To answer this question this study examines the UK's enterprise policy process in the 2009-2010 period. It suggests that a key factor for the ineffectiveness of policy is how it is formulated. This stage in the policy process is seldom visible to those outside of government departments and has been largely ignored by prior research. The application of institutional theory provides a detailed theoretical understanding of the actors and the process by which enterprise policy is formulated. We find that by opening up the 'black box' of enterprise policy formulation, the process is dominated by powerful actors who govern the process with their interests.
\end{abstract}

\section{Key words}

Enterprise policy, Formulation, Institutional theory, Institutional entrepreneur, Legitimacy, Power, Qualitative

\section{JEL classification}


Introduction

Promoting entrepreneurship is a central theme in the economic strategies of governments around the world, dating back over the past thirty years in the case of the UK (Burton 2006; Blackburn and Smallbone 2008). Enterprise policies ${ }^{1}$ are based on the belief that public sector support of entrepreneurial activity helps drive economic growth, increases employment and strengthens international competitiveness (Audretsch and Beckmann 2007; Van Praag and Versloot 2007). Such policies are considered to be the most important policy instruments for a global and knowledge based economy (Gilbert et al. 2004). Yet despite their popularity, the effectiveness of enterprise policy is questioned (Curran and Storey 2002; Richard et al. 2007; Huggins and Williams 2009; Williams 2013), with critics attributing its lack of effectiveness to the way in which policy has been implemented. However, Shane (2009, p. 142), writing in Small Business Economics, offers a more fundamental explanation for the lack of effectiveness of enterprise policy, simply that it is "bad public policy." He argues that "there is a lot of evidence that these policies lead people to start marginal businesses that are likely to fail, have little economic impact, and generate little employment" (Shane, 2008, p. 158). Previously, Storey (2000, p. 276) had made a similar point, arguing that enterprise policies which are currently pursued, are "rarely specified and appear to reflect the need to do something or seen to be responding, rather than as part of a coherent agenda designed to achieve clear objectives." But this begs the question why the legislative process produces 'bad' public policy? Recent analyses suggest that it may be attributable to the ways in which policy ideas originate and develop (Dennis Jr 2011; Williams 2013). Most of the enterprise policy literature has focused on the implementation (Mole 2002; Xheneti and Kitching 2011; Vega et al. 2013) and evaluation stages (Storey 2002; Bennett 2008; Lenihan 2011; Cowie

\footnotetext{
${ }^{1}$ Policy documents tend to be vague in the terms they use. Enterprise, entrepreneurship, small and medium enterprises (SMEs), small business ownership and self-employment are terms used frequently and synonymously. In this study 'enterprise policy' denotes all entrepreneurship and SME policy aimed at fostering business start-up and growth rates (Audretsch and Beckmann 2007; BERR 2008). Entrepreneurship policy and SME policy are separate entities but have similar long-term visions. After studying different economies, Lundstrom and Stevenson (2005, p. 5) define entrepreneurship policy as being "aimed at the pre-start, the startup and post-start-up phases of the entrepreneurial process... and has the primary objective of encouraging more people in the population to consider entrepreneurship as an option, to move into the nascent stage of taking the steps to get started and then to proceed into the infancy and early stages of a business." In contrast, SME policy targets the existing population of enterprises, encompassing a range of support measures to promote their viability (Audretsch 2004). But in reality the lines between entrepreneurship policy and SME policy are often blurred. While there is considerable overlap, both have the same aim of enhancing economic prosperity. In the UK, both policies are collectively referred to as 'enterprise policy' (BERR 2008; Lenihan 2011); accordingly, this is the term used in this paper.
} 
2012; Jones et al. 2013). Scholars such as Storey (2000, 2002) and Bennett (2008) have concentrated on how and why enterprise policy should be assessed. In contrast, the policy formulation stage of the enterprise policy process has attracted little serious attention from entrepreneurship and small business scholars and remains hidden from view (Dennis $\mathrm{Jr}$ 2011). The little that is known about enterprise policy-making indicates it is complex and messy (Lundstrom and Stevenson 2005).

Accordingly, the focus of this paper is on the formulation of enterprise policy, specifically whether the formulation element is at the core of the ineffectiveness of enterprise policy. As such, opening up the 'black box' of the policy formulation process provides an insight into how enterprise policy is formulated in the UK and using institutional theory to analyse and explore the involvement of multiple actors within the institution. This focus is apposite because little is known about the enterprise policy process, particularly how it is shaped (Lundstrom and Stevenson 2005). This study makes two contributions to the current enterprise policy debate. First, by focusing on how enterprise policy is formulated it examines a previously unexplored stage of the policy process to reveal a potential underlying source of policy ineffectiveness. As Karlsson and Andersson (2009, p. 127) argue, "there is still a gulf between our understanding of the need for entrepreneurship policies and how such policies should be designed when needed." Second, it provides an insight into the key actors (policy-makers, civil servants and ministers) involved in the policy process, thereby illustrating Ram and Trehan's (2010, p. 417) view of enterprise policy-making as "a process of argumentation that emerges from dialogue, interpretation, experience and prevailing power structures." Drawing on institutional theory, the study returns to the 'coalface' of institutions to highlight the dynamics of the enterprise policy process at the macro and micro-levels (Barley 2008; Fisher 2012), adopting a qualitative approach to gain an understanding of the often complex relationships and processes of government and policy. Specifically, this is the most appropriate approach in addressing "how" questions rather than "how many" for understanding the world from the perspective of those studied (i.e. informants) and for examining and articulating processes (Pratt 2009). A quantitative approach was disregarded because emphasis is placed on quantifying relationships between variables which is not always possible and was not the ideal approach given the exploratory nature of the study. 
Scholars have long stressed the importance of developing government policies ${ }^{2}$ in a way that improves the effectiveness of both government and policy (Linder and Peters 1990). In the UK, a series of government reports - notably the White Paper Modernising Government (Cabinet Office 1999) and Better Policy-Making (Bullock et al. 2001) - have sought to develop best practice for formulating and evaluating government policies. The Green Book (HM Treasury 2005) considers standard operating procedure (in its most simplistic view), describes the ROAMEF Cycle (Rationale, Objectives, Appraisal, Monitoring, Evaluation and Feedback) and proposes how policy should be formulated and the stages that the process should pass through. Despite these attempts to improve the quality of policy-making, problems remain. Enterprise policies are often based on unclear and distorted objectives leading to ambiguous aims and weak monitoring and measuring (Fischer et al. 2006). Evaluations are meant to provide feedback to policy-makers and enable continual assessment of a policy's effectiveness, but they often focus on short-term outputs rather than longer-term policy outcomes - with potentially misleading results (Hewitt-Dundas and Roper 2011). Short-term outputs convey the tangible outcomes required for meeting the electoral imperatives facing politicians (Mason and Brown 2013), which in many cases may mean formulating policy to address political agendas. Regardless, policy-makers continue to promote enterprise policy because the potential economic and social value of entrepreneurship is considered to be large.

In the UK, enterprise policies have appeared in various guises since the 1970 s, following the seminal Bolton Report into the future of small businesses (Bolton 1971). Since then successive governments have introduced a variety of programmes of public intervention at the national and/or regional/local level (training, loan guarantees and finance counselling) with the broad intention of creating an 'entrepreneurial society' (Gibb 2000; Blackburn and Smallbone 2011). The level of direct government support for SMEs has increased significantly over the last couple of decades, and now includes a range of financial measures

\footnotetext{
${ }^{2}$ As with many other concepts in the social sciences, 'policy' is an ambiguous term whose meaning has changed over the years (Sapru 2010). We adopt Parsons' (1995, p. 14) definition of policy as "an attempt to define and structure a rational basis for action or inaction." Policies are formulated by "authorities" who "engage in the daily affairs of a political system" (Easton 1965, p. 212). The policy-making process comprises several distinct stages, including agenda setting (policy formulation), specification of alternative actions (policy choices), authoritative choice of action (policy decision) and implementation (Kingdon 1984).
} 
known as 'hard' policy instruments, such as direct grants, loans, loan guarantees and venture capital initiatives, and 'soft' business support, such as advice, guidance on best practice and access to gateway services to help them address particular challenges (Wren and Storey 2002; Lambrecht and Pirnay 2005). This array of enterprise policy initiatives is estimated to cost the UK government around $£ 12$ billion a year and accounts for $2 \%$ of all government expenditure (Richard et al. 2007). Although Bennett (2008) provides a positive review of government support, others argue that the support is not always effective or value for money (Van Cauwenberge et al. 2013).

Despite criticisms, governments continue to introduce policy instruments. While in North America the government follows a low regulation model to increase the amount of start-ups, many European countries, like the UK rely on a high support route (Van Stel et al. 2007). For example, the Enterprise Finance Guarantee scheme has committed to pledging $£ 2$ billion in loans over four years and the Start-Up Loans scheme has been allocated by $£ 30$ million; the commitment to reducing bureaucracy has guided the government's agenda for regulatory reform highlighting the current 'one in and one out' regulatory rule; Startup Britain was launched in 2011 to deliver support and advice to entrepreneurs; and Enterprise Zones have been (re-)introduced to create jobs by incentivising firms to move to depressed areas (Department for Business, Innovation \& Skills 2012; Young 2013). But as the number of initiatives has grown so has criticism. It is evident that there is no shortage of enterprise policy initiatives being offered to business. However, the outcome of all this activity is a business support system that is hard to "navigate, evaluate and manage" (Centre for Cities 2013, p. 1).

Prior research has described the different enterprise policies that support the SME sector (Lundstrom and Stevenson 2005), explained why such policies are important (Bennett 2008) and evaluated their impact (Storey 2000; Curran and Storey 2002; Greene 2009). These studies highlight the general lack of improvement in business start-up rates over time despite the high level of spending on measures designed to promote an enterprising society, leading to the conclusion that state support for enterprise has been generally ineffective (Richard et al. 2007; Greene et al. 2008; Huggins and Williams 2009; Shane 2009; Bridge 2010). As Bannock (2005, p. 133) argued, "with a few exceptions, results are unimpressive - and even for the exceptions, they are fairly marginal in their effects. There is no reason to suppose that 
if most subsidies and assistance programmes were abolished altogether, it would make a significant difference to the shape and prosperity of the SME sector anywhere."

This study focusses on understanding how the enterprise policy process works, given that the growing evidence suggests that policies aimed at entrepreneurship are not yielding the results governments are hoping for (Welter 2011). As Blackburn and Smallbone (2011, p. 575) argue, "developing public policy for SMEs may appear straightforward on an issue-by-issue basis. However, in practice, developing a policy landscape that is conducive to SMEs, as well as meeting the demands of other stakeholders in the economy and society, is not easy."

\section{Theoretical framework: Institutional theory}

This study draws on institutional theory as a lens to examine the process of enterprise policy formulation and the key actors involved. Although institutional theory is more commonly used to explain entrepreneurial behaviour, it is relevant here because we "should not only know more about institutions, their role in economic development, and how they change, but also how a great number of actors with divergent interests, varying normative commitments, different powers, and limited cognition create and recreate institutions" (Streeck and Thelen 2005, p. 16). A central focus of the theory is institutions, which are the "rules of the game in a society" that "affect the performance of the economy by their effect on the cost of exchanges and production" (North 1990, pp. 3-5). Two types of institutions have been recognised: formal institutions (i.e. those that are created for example, from social norms, laws, constitutions) and informal institutions (i.e. those that evolve over time, for example, from traditions, culture, taboos) (North 1990). This paper recognises the government as the formal institution, first, because it involves key individuals who have substantial and unrivalled power to shape enterprise policy (Grimm 2006), and second, because they are part of the government and the state they can either encourage or impede economic activity through regulations and restrictions (Acs et al. 1997; North et al. 2001). Institutional theory demonstrates how institutional pressures can influence organisational processes and practices over time. Given this, the focus of the study is on the processual element of the formation of enterprise policy and the individuals involved rather than on the outcomes of the process. We are not assuming that the formulation of enterprise policy leads to ineffectiveness of the policy itself but rather that there is a likelihood of the formulation of enterprise policy playing, to some extent, a role in the outcome. We attempt to bring greater transparency to 
the process since the positive effects of entrepreneurship will depend on its institutional arrangements and the social payoff structure (Baumol, 1990).

The application of institutional theory allows us to examine how processes are created, diffused, adopted and adapted to fit within institutional structures (Scott 2001). Institutional theory describes the processes by which these structures, schemas, rules, norms and routines become embedded in society (Scott 2004), and enables researchers to determine the process and the relationships between the macro (government) and the micro-levels (actors). Discussions are often conducted at the macro-level, demonstrating that enterprise policy at the micro-level where actors play a dominant role, has little impact on the entrepreneurial economy (Bennett 2008) because at the micro-level, institutional entrepreneurs ${ }^{3}$ (who may be politicians, policy-makers or civic activists) are involved in developing such policies at national and regional levels (Sotarauta and Pulkkinen 2011). In other words, actors within this context are the individuals who have the authority, power and resources to dictate not only the processes but the outcomes. Often in entrepreneurship studies, institutional entrepreneurs are referred to as those individuals who are embodied in an organisation and assist in transforming institutions in order to introduce new social or cultural forms or logics into society (Aldrich 2011). However, institutional entrepreneurs in the field of entrepreneurship are not necessarily embodied in organisations, their efforts can be employed "to identify political opportunities, frame issues and problems, mobilise constituencies, and spearhead collective attempts to infuse new beliefs, norms and values into social structures" (Bruton et al. 2010, p. 429). In other words they are agents pursuing certain interests and acting strategically (Weik 2011).

Aldrich (2011) argues that rather than the individual efforts of institutional entrepreneurs playing an important role in the field of entrepreneurship, institutional entrepreneurship should be considered as a 'collective process' which allows us to refer to the collective actions of individuals and other entities to (assuming policy-makers are included in this concept) transform institutions (Aldrich and Fiol 1994; Aldrich 2011). Thus institutional entrepreneurship can explain the formulation of enterprise policy (Garud et al. 2007) even though some neo-institutional theorists may disagree (Battilana 2006). Our understanding is

\footnotetext{
${ }^{3}$ This paper subscribes to DiMaggio (1998) and Fligstein's (1997) concept of institutional entrepreneurs. These authors define institutional entrepreneurs as actors who have sufficient resources to create new institutions which serve their interests, and who display a range of social skills (Leca et al. 2008).
} 
that institutional entrepreneurs (policy-makers) have the resources to ensure change happens and institutional entrepreneurship is a powerful way of explaining the role played by actors in internal institutional change and in capturing the nuances of process models (McGaughey 2012; Jennings et al. 2013). It is necessary to link the individual level of analysis back to the organisational and societal ones. The objective of this approach is to explain under what conditions individuals are enabled to act as institutional entrepreneurs (Battilana, 2006) and institutional entrepreneurship allows a form of process-oriented inquiry where the role of actors is fleshed out by analysing the change processes. The collective process of institutional entrepreneurship highlights agency, interests, legitimacy, and power in the understanding and analysis of how enterprise policy is formulated (Levy and Scully 2007). These key themes, particularly in connection with institutional entrepreneurs allow analysis to be undertaken (Table 1).

\section{INSERT TABLE 1 ABOUT HERE}

Current literature emphasises legitimacy as an important concept of institutional theory (Bitekine 2011). It is "a generalised perception or assumption that the actions of an entity are desirable, proper, or appropriate within some socially constructed system of norms, values, beliefs, and definitions" (Suchman 1995, p. 574). By creating legitimacy the institutional entrepreneurs and institutions create stability and predictability through improving efficiency and reducing uncertainties (Scott 2001). Institutional theory suggests that organisations make structural decisions on the basis of legitimacy rather than on efficiency. Meyer and Rowan (1977, p. 349) argue that "incorporating externally legitimated formal structures increases the commitment of internal participants and external constituents." Obtaining legitimacy has been shown to be an important issue for institutional frameworks (Delmar and Shane 2004). There are three types of legitimacy that the institution fostered. Firstly, internal legitimacy predicated on the impartiality of policy-makers, the process and on the policy itself; secondly, external legitimacy involving the role of external stakeholders, such as Task Forces, RDAs and delivery agencies; and thirdly, media legitimacy informing the public of such a policy (Bitektine 2011). The enterprise policy process, the enterprise policy itself and the people within the institution require legitimacy because of the belief that their behaviours and practices will only establish credibility once they are socially accepted by others. 
Oliver (1991) is one of the few institutional scholars who has given attention to notions of power, arguing that power derives from institutions and shapes the course of institutional change. Power, neglected in earlier studies in institutional theory, has become much more apparent recently following institutional entrepreneurship's re-introduction of agency (Delbridge and Edwards 2007). Power is a driver of institutional change, in which powerful institutional entrepreneurs can shape the institutional environment depending on their particular interests (Pacheco et al. 2010). However, institutional entrepreneurs often have varying levels and forms of power which can influence tactics and set agendas given their interests (Maguire et al. 2004).

Institutional theory has been criticised for its "lack of due attention to agency and interest" (Mutch 2007, p. 1123) and the "lack of attention to the role of actors in creating and promulgating innovations" (Lounsbury and Crumley 2007, p. 993). This disregard of agency is largely a feature of new institutionalism and, because old institutionalism connects much more clearly with action, this deficiency can be overcome by reconciling the new and the old institutionalisms (Hirsch and Lounsbury 1997). DiMaggio (1988, p. 13) attempts to relocate interest and agency to a focal position in the theory, suggesting that institutionalisation can be seen as "a product of the political efforts of actors to accomplish their ends and that the success of an institutionalisation project and the form that the resulting institution takes depend on the relative power of the actors who support, oppose, or otherwise strive to influence it." The focus has primarily been on organisational adaptations resulting from institutional pressures including social values, norms and expectations imposed by the external environment without a great deal of consideration given to the influence of active agency and external exchange relationships that play a part in driving organisational change (Oliver 1991).

Institutional theory acknowledges the evolution of institutions, organisations and in more recent times the actors involved in understanding how they locate themselves in social relations and interpret their context. By concentrating on this, the micro-level explanations give more depth to analysing explanations and critiquing macro-level events and relationships. This also provides a link between institutions and action. The theoretical lens illustrates actions, decisions and relationships of those involved in the phenomenon. Given the understanding of institutional theory, each theme intrinsically links to one another: legitimacy, institutional entrepreneurs, power, interest and agency. They are inter-dependent 
on one another because an institutional perspective on policy formulation, as argued by Linder and Peters (1990, p. 61) "permits us to reconsider the role of information in the formulation process and to offer a richer conception of the institutional dynamics involved." This highlights the evolving nature of such processes. Although policy formulation and behaviour are linked to wider social and cultural beliefs, these structures can change as people go about their work and as they implement policies and plans (Burch, 2007). Hence, there is every possibility that each theme is not only intrinsically linked with each other but relies on each other because their roles (agency) as powerful actors (institutional entrepreneurs) and their motives (power and interest) dominate the process in which the outcome of enterprise policy is accepted by internal and external stakeholders (legitimacy). This study seeks to use institutional theory to understand and explain rational-actor accounts (March and Olsen 1984). This shifts attention back to policy-makers and civil servants and the infrastructures of institutions in order to carry out analysis at both the micro-level and at the macro-level.

At the macro-level, institutional dynamics explain the changes occurring within institutions whilst at the micro-level, they explain how these changes are perceived and experienced by individuals, including institutional entrepreneurs. The entrepreneurship literature has focused on explaining behaviours at the micro-level and there has been little discussion of behaviours and processes at the macro-level. Institutional theory is particularly relevant for understanding the impact of internal and external influences on organisations that are engaged in change programmes such as policy processes (Vishanth et al. 2009). An institutional approach not only allows the research to open up the 'black box' of formulating enterprise policy without having to add on layers of complexity in explanations at an individual level (Linder and Peters 1990), but it also enables the exploration of the interaction between actors and their institutional setting (Sotarauta and Pulkkinen 2011).

Figure 1 presents a conceptualisation of the policy process. Figure 1 is a simplistic version of a much larger and complex network of institutions and individuals involved in the policymaking process. However, the scope of the paper is limited to the four main stages of the policy process which loosely follows Kingdon's (1989) distinct stages. This paper focuses on the activities and institutional entrepreneurs represented in the shaded area. While previous studies have focused on public-facing aspects of enterprise policy (Stages 1, 3 and 4), this paper explores the hidden process of policy formulation (Stage 2) by seeking out those actors 
within government (ministers, civil servants and policy-makers) who are not generally accessible. Although the Regional Development Agencies (RDAs) ${ }^{4}$ and Local Enterprise Agencies (Stage 3) played an important role in policy implementation at the time, their activities were outside the scope of this study. The theoretical lens focuses primarily on those government actors within the institution who influence political decision-making and the formulation of enterprise policy (Baumol 1990).

\section{INSERT FIGURE 1 ABOUT HERE}

Stage 2 begins with those civil servants and policy-makers who allocate the resources necessary to enact enterprise policy. The government is responsible for setting up and enforcing the rules under which entrepreneurs operate (Sobel 2008). These rules influence the nature of how entrepreneurship occurs (Campbell 2012). The government sets the direction for economic development with limited involvement from external stakeholders in the policy process (Cornett 2009). In any economy, the government is the key determiner of the external environment in which businesses develop (Smallbone and Welter 2010; Stenholm et al. 2013). At Stage 2, the institution and its actors have the power to determine economic performance because the laws and practices they establish shape individuals' behaviour. Since these laws and practices are readily identifiable, they make a convenient point at which to begin the analysis (Peters 2000).

\section{$4 \quad$ Research methods}

A qualitative methodology is used to explore the process and actors involved in enterprise policy formulation as institutional theorists have encouraged a move away from positivistic research (Suddaby 2010). In-depth interviews and participant observation were seen as being the most effective methods of gathering data, allowing explorations of behaviour, attitudes and needs of individuals. As Bevir and Rhodes (2003, p. 82) argue, institutions are the products of the "diverse beliefs and actions" of their inhabitants - in this case, the civil servants and policy-makers who work there. The research was conducted in a government

\footnotetext{
${ }^{4}$ The RDAs were abolished in March 2012, to be replaced by Local Enterprise Partnerships. The goal of Local Enterprise Partnerships is to assist in determining local economic priorities and leading economic growth and job creation.
} 
department responsible for enterprise policy ${ }^{5}$. The specific department within the wider government ministry, the team and the job titles of those involved remain confidential. The participant observation was well documented and all legal formalities were followed to ensure that confidentiality, anonymity and security issues were adhered to, and security clearance was approved given the government protocol for such data collection.

The purpose of the in-depth interviews was to gain a comprehensive understanding of how policy-makers understand enterprise policy and how they contribute to the formulation process. The semi-structured interview format enabled a series of questions to be framed in advance, enabling comparability, while also leaving room to pursue unexpected lines of enquiry. It was essential to interview several highly knowledgeable informants who had different perspectives of the focal phenomenon (Eisenhardt and Graebner 2007). The government department had created a dedicated a team responsible for the enterprise agenda. The interviewees were selected from those members of the team who were dominantly involved in the policy process. These individuals could be regarded as the gatekeepers of the enterprise policy process. Eight interviews with policy-makers were undertaken.

These interviews were complemented by participant observation techniques which provided insights into how enterprise policy is formulated which would not have been possible from interviews alone. The personal rapport established with certain individuals led to them to agree to first-named author taking on the role of a participant observer (Policy Advisor) within the government department in London for three months. The data collected involved undertaking 3 months as a participant observer within the department. A daily diary reported activities and observations about relationships and dynamics of individuals and the department, and a further 32 meetings were attended within the government department. The aim was to use this active involvement within the department to produce an insider-oriented account (Hammersley and Atkinson 1995), predicated on the assumption that the insider's perception (the emic perspective) is instrumental in understanding and accurately describing situations and behaviours (Fetterman 2010). The focus was on understanding processes which captured "the full range of data nuances and conditionality" (Mason and Rogers 1997, p. 31), especially when decisions were actually being made (Ekanem and Smallbone 2007). The

\footnotetext{
${ }^{5}$ The term 'policy-maker' indicates the individuals who were interviewed, while the term 'civil servant' refers to the individuals involved in the participant observation stage of the research. Both formulate enterprise policy; however, the distinction better depicts the different data collection methods used in this study.
} 
focus on processual issues is replicated in this paper, which explores the process of enterprise policy formulation, concentrating on the political and social micro-levels (Bayard deVolo and Shatz 2004).

Triangulation was used as a measure for strengthening overall validity for both the interviews and the participant observation. Triangulation involved confirming the accuracy of data from one source of data collected from another source (LeCompte and Schensul 1990). Strategies included both data triangulation and methodological triangulation (Denzin 1978; Patton 2002). Data triangulation involved the collection of a variety of sources in the study which included gathering data from numerous sources such as internal documents, organisational documents, and secondary published materials and also from the primary data gathered. Methodological triangulation involved gathering data from multiple informants, which involved the use of numerous methods within or across research approaches (in-depth interviews and participant observation) ${ }^{6}$.

\subsection{Research context}

The government department that was the focus of the study contains several different management levels. A hierarchical chart was created to clarify the position and seniority level of respondents whilst undertaking participant observation (Figure 2). The Managing Director (MD) is the head of department, reporting directly to the Permanent Secretary. Staff at the Senior Management (SM) ${ }^{7}$ level report directly to the head of department and make top-level decisions concerning their team. Middle Managers (MM) are directly responsible to senior

\footnotetext{
${ }^{6}$ The first named author undertook the interviews and the participant observation. Because of the subjective nature of the research and the methods employed, it was important that a description was given of how, when and where the field work of this study was carried out and how, when and where notes, journals and records were kept and organised. In doing so, issues regarding the critical reflection process on the self as a researcher, the human as instrument were addressed (Guba and Lincoln 1981). Reflexivity is the conscious experiencing of the self as both inquirer and respondent, as teacher and learner, as the one coming to know the self within the processes of research itself (Guba and Lincoln 2005). On a deeper level reflexivity allowed the researcher to question the methods and the theoretical framework they work within, and to validate and legitimise the decisions that were taken in undertaking the current study. We understood and accepted the competing versions of reality by providing accounts of researchers' personal background, biases, preconceptions and research activities to improve the legitimation of the data (Brewer 2000).

${ }^{7}$ SM (PM9) and SM (CS4) were responsible for their team but during the collection of the primary data there was a changeover in position. During the interview period SM:PM9 was in this position, at the time of undertaking the participation observation, this position was then undertaken by SM:CS4.
} 
management. They pursue the organisational goals set by senior management, deploying and controlling resources within established guidelines. Junior Management (JM) carry out the day-to-day duties, including the supervision of non-managerial staff. Apart from the head of department, only those who were interviewed or part of the participant observation study are included in Figure 2. The interviews were not conducted in any specific order.

\section{INSERT FIGURE 2 ABOUT HERE}

\subsection{Data collection and analysis}

The interviews and participant observation were undertaken towards the end of the Labour administration in 2009-2010. The interview questions encouraged respondents to describe their own experiences and knowledge of the formulation of enterprise policy, with the discussion based around a policy document, Enterprise: Unlocking the UK's Talent ${ }^{8}$ (BERR 2008). This approach was effective in terms of understanding the experiences of the formulation of enterprise policy and strengthened the validity of the interviewees' information.

Interviews were recorded and transcribed verbatim. Transcripts were sent to interviewees to be amended, updated and confirmed. A daily diary kept for the duration of the observation period helped to overcome any potential researcher bias (Fine et al. 2010). Analysis, which began during the interview and observation stages, aimed to order, structure and interpret the data and to identify any relationships and underlying themes (Marshall and Rossman 2006). NVivo was used to note and code simultaneous themes and patterns. The priori themes (whose selection was guided by institutional theory) included those themes that had been used to structure the interview scripts (e.g. understanding the formulation of enterprise policy). All codes were named and given an individual 'node.' There were 37 tree nodes, each with sub-nodes. These themes were modified following repeated readings of the text (King 2004). As interview excerpts were interpreted, the data were re-examined, re-coded

\footnotetext{
${ }^{8}$ At the time this document was seen as the Government's renewed enterprise vision to make the UK the most enterprising economy in the world and the best place to start and grow a business (BERR 2008). The White Paper's policy proposals also saw the government successfully implement various recommendations from the Paper. For example, an Academy for Enterprise (headed by Peter Jones) was introduced and $£ 30$ million was committed to extend enterprise education.
} 
where appropriate and key concepts were linked (Emerson et al 1995). The purpose of this stage of the analysis was to ensure that the theoretical ideas which had emerged in the first round of coding could be systematically evidenced in the data, in which three dominant theoretical themes became apparent: legitimacy, institutional entrepreneurs, power, and agency and interest.

\section{$5 \quad$ Findings and discussion}

The research findings are presented in the following two sections. The first describes how policy-makers perceived the formulation of enterprise policy (idealistic view), while the second demonstrates how enterprise policy was formulated in practice (realistic view). Key themes were drawn from institutional theory. Legitimacy is a dominant theme in both the idealistic and realistic view of enterprise policy-making. The quotes that are used in the paper are the most representative of the research findings (Patton 2002).

The theoretical themes intrinsically became inter-dependent and reliant on each other for the process of enterprise policy-making to move from one phase to the next. In other words, the process was legitimised because institutional entrepreneurs with power made key decisions, involved stakeholders and announced positive promises. The institutional entrepreneurs had an interest in specific institutional structures and commanded resources which were applied to influence institutionalised rules (Beckert 1999), in this case enterprise policy-making. Both the institution itself and the institutional entrepreneurs shaped the process, with emphasis placed on legitimacy rather than on the effectiveness of the formulation of enterprise policy. Furthermore, power emerged as a finding because of the structured hierarchy, with certain key actors skilfully manipulating the process to pursue their own personal needs and goals. The findings also illustrate the importance of agency, confirming that embedded actors can shape institutions as well as processes (Leca et al. 2008) because agency provides "a richer understanding of how individuals might actively and reflexively maintain institutions, even while fulfilling socially prescribed roles" (Lawrence et al. 2011, p. 54). 


\subsection{Challenging the ideal approach to enterprise policy formulation}

The interviews with the policy-makers indicated that while they are aware of how the formulation process should ideally work, they recognise that the reality is often rather different. The formal process was best explained by SM:PM1, who defined it in terms of the ROAMEF Cycle (HM Treasury 2005):

The first step is supposed to be looking at the rationale, why there's a need for policy, looking at the evidence, the extent of any problem. So that's the first steplooking at the rationale, looking at the evidence-base, from that you're supposed to go on to develop objectives of what you're trying to achieve with policy which is supposed to be as SMART [Specific, Measureable, Achievable, Realistic and Timely] as possible. This is all well documented. And then, obviously there are various ways of achieving different objectives and each way has got different costs involved so the next step is then supposed to be an appraisal of all the different methods of achieving the initiatives. The next thing you're supposed to do is do a full cost-benefit analysis of all the different options and work out from that which is the best. At the same time as the policies are being designed you're supposed to develop the monitoring framework to assess whether you're meeting your objectives, plus an evaluation plan to get at the wider economic impacts, say productivity or employment, depending on the objective.

Whilst SM:PM1 argued that policy is developed using a rationale, the underlying logic is not always clear (Cowie 2012). JM:PM3, who was present at the same interview, observed that the policy process is not always straightforward in practice:

[SM:PM1] has given you a bit of an idealistic model. However hard you try and work it's not always that easy in practice....not because people aren't trying but some things are quite difficult. [SM:PM1] was saying you have to appraise your options but I mean ministers and senior people have to make decisions on where to spend a limited amount of money. So what you have to be able to consider is the relative merits of different policies or policies in different areas. 
SM:PM1 was keen to justify and endorse the enterprise policy process, illustrating the truth of Suchman's (1995, p. 574) observation that "legitimacy is a perception or assumption in that it represents a reaction of observers to the organisation as they see it; thus legitimacy is possessed objectively, yet created subjectively." JM:PM3 understood the reasons and mechanisms that underlie the creation of enterprise policy but was also aware that, in practice, policy-making is more complicated and less structured than the theory acknowledges.

SM:PM1 conceded that their summary reflected how policy formulation is supposed to work but accepted that:

Whether it works like that in practice is a different matter, mainly because of ministerial and political imperatives.

These comments from the two policy-makers seem to challenge the official view that policymaking is a structured, linear process. They also acknowledged the importance of powerful institutional entrepreneurs, admitting that a powerful and charismatic minister can dominate the formulation of enterprise policy. JM:PM4 commented that enterprise policy 'can be on the whim of ministerial changes or personalities.' Thus, formulation often deviates considerably from the idealised model, which clearly has little relevance to day-to-day operations. Ministers were seen by the interviewees as the initial drivers of the process, deciding which issues to pursue and prioritise. Their comments highlight the role played by powerful institutional entrepreneurs, and may raise concerns as to how far ministers should be involved in policy formulation and whether they are overriding the prescribed model.

In summary, the policy-makers described a rational model of policy-making, but acknowledged that this model is not followed in practice. Selznick $(1949$, p. 10) noted that "the most important thing about organisations is that, though they are tools, each nevertheless has a life of its own." Although they are rationally designed to achieve defined goals, formal structures can never conquer the non-rational dimensions of organisational behaviour. Individuals are not influenced solely by formal roles and structures. Other commitments may also affect their capacity to make rational decisions. The perceived reality of formulating enterprise policy was acknowledged by the civil servants. They understood the importance of 
legitimacy (adhering to, or at least trying to work to a formal procedure), with powerful ministers dictating their self-interest above the formal structures within the institution.

\subsection{Enterprise policy formulation in practice}

The participant observation phase of the data collection indicated that the process was distinguished by a lack of transparency and procedure. The evidence suggests six phases of enterprise policy formulation: the identification of an area of policy interest, briefing, collecting evidence, clearing, announcements and implementing. Though these phases were discrete, the process was not linear. Table 2 highlights the dominant theoretical themes in the process of enterprise policy formulation.

\section{INSERT TABLE 2 ABOUT HERE}

\section{Phase 1: Area of enterprise policy interest}

The first step is the emergence of an area of enterprise policy interest. This can come from a variety of sources including ministerial interest. Ministers may perceive a need to do something or be seen to be doing something. When it is recognised that a new policy needs to be developed, there is usually discussion of how it should be carried out. The individual preferences of a particular minister or official have considerable influence over the outcome (Waller et al 2008). One policy-maker commented:

I think a lot of it depends on ministerial interests, I mean looking at the topic I've been working on [project name deleted] over the last few years, there has been a noticeable difference in support depending on which minister is in post at any given time (JM:PM3).

Another policy-maker remarked that: 'I think pretty much of it [policy formulation] is ministerial interest' (JM:PM4), highlighting that ministers are central to the orchestration of policy formulation (Oborn et al. 2013, p. 254).

The discussions with civil servants revealed that policy ideas do not always originate with ministers. JM:CS1 and JM:CS2 both referred to a fellow senior civil servant as having 
'planted seeds' in a minister's mind to encourage them to support certain policy interests. JM:PM3 stated:

I think it is important to actually work with ministers, in particular private offices, to raise the profile or the agenda. That's part of the job of any good civil servant, to bring to the attention of ministers topics which need development or which could bring benefit.

The involvement of talented civil servants as well as ministers helps further legitimise and endorse the policy interest (Deephouse 1996). However, these individuals are themselves decision-makers within a 'dominance hierarchy' (DiMaggio and Powell 1983) or "dominance order in which a few groups of actors operate at the apex while others survive on the bottom" (Rao et al. 2000, p. 262). The findings reflect Maguire et al.'s (2004) study in which institutional theory highlights institutional change as a political process that echoes the power and interests of organised actors. The findings also suggest that policy interests are dictated by the individual values and political beliefs of ministers and civil servants, and then framed in such a way as to gain wider support. Institutional entrepreneurs act as catalysts to the policy process within this given phase because they manage and shape the policy interests. No indication was given to suggest that policy interests are formed in response to evaluations, justifications (e.g. market failure) or evidence (e.g. commissioned reports). Rather, it was often left to individual personalities and interests at the cost of developing policy interests of benefit to the SME sector. In summary three themes were dominant in the first phase of the formulation of enterprise policy: the search for legitimacy, the interest of institutional entrepreneurs, and the power they have in embedding their self-interest in the institutional process. These themes became apparent as the starting point for the remainder of the process.

\section{Phase 2: Briefing}

The briefing phase involves meetings to allocate tasks such as the gathering of evidence, liaising with stakeholders ${ }^{9}$ and updating the team. The civil servants involved at this phase are usually those with experience of formulating enterprise policy. The purpose of the briefing phase is to refine the policy interest into a legitimate, achievable and deliverable idea and to provide updates to the middle management of the civil service.

\footnotetext{
${ }^{9}$ Stakeholders refer to non-governmental actors.
} 
Briefing phase meetings were embedded in the everyday work culture of the civil servants. However, little time was given to discussion of how the policy idea could be mobilised. Rather, importance was placed on justifying the idea itself. More often than not, the meetings centred on ministerial announcements and how the relevant minister could use the policy interest to achieve a strong media presence, increase their electoral support and strengthen their reputation. The briefing phase highlights the numerous which were set up to discuss the policy interest, emphasising shared norms and values between the policy-makers and their minister (Scott 2001).

The meetings culture can be attributed to the perceived need among the civil servants to strengthen the internal legitimacy of the policy formulation process. Civil servants were refining and reinforcing the political interests of their minister as well as nurturing the credibility of their own work. Despite the lack of structure and progress at these meetings, it was generally accepted that attendance by civil servants was obligatory. The briefing phase also involves bringing in external stakeholders who then become part of the formulation process. These handpicked stakeholders, for example Task Force members, drawn from among the 'great and the good', represent an attempt to increase the external legitimacy of the process (Polsby 2001). However, civil servants emphasised that the involvement of these external stakeholders is symbolic. They are not government advisors, nor do they have any influence on enterprise policy formulation. Rather, they are seen as intangible resources to impose their institutional projects (Leca et al. 2008). The second phase indicated that legitimacy was of great importance. Stakeholders were sought as they were crucial for establishing legitimacy, allowing access to resources, and even to organisational survival (Greenwood et al. 2011).

\section{Phase 3: Collecting evidence}

Once a policy interest has been identified and briefing meetings are underway, the next phase in the policy formulation process is the gathering of data. This task is undertaken by civil servants, with their role being to gather evidence that will support and justify the proposed policy interest. Two features of this phase are therefore significant: first, that ministers rely on civil servants to collect the evidence and second, that the collection of evidence is politically motivated. 
Ministers remain important institutional entrepreneurs in policy-making in the UK. Amongst their various duties, they decide priorities and authorise the work of the policy-making process (Waller et al. 2008). Civil servants therefore have to 'fit' a story with evidence around ministerial interests. JM:PM5 commented that:

I think where there's political will, things happen. Sometimes all the evidence in the world is irrelevant depending on what political leadership wants to do.

Moreover, the quality of the research is often questionable. The 'generalist' tradition of the civil service and regular rotation between departments mean that the civil servants undertaking the research are not necessarily experts on the topic. An example of this was SM:PM9 and SM:CS4, who both came from different government departments. SM:PM9 was only in the post for a short while before being transferred again to another government department. Evidence often takes the form of a narrative rather than hard data. One respondent commented:

I'm not an expert in this area so this is more anecdotal (JM:PM7).

Also, the need to collect the data in a short period of time has adverse implications for its quality:

The robustness of our evidence, especially on finance related issues to all our groups, was negated and we had to find new ways of gathering data quickly and often it was not robust...(SM:PM1).

Accordingly, much of the analysis and information may be 'up in the air' (SM:PM1). Or, more simply:

We didn't have time to do proper research, we had to be more innovative in the kind of resources we used, we drew heavily on other people's surveys that might not always be representative to try and get a balance of what was happening (JM:PM2).

The findings highlight that enterprise policy formulation is subject to political interests and is driven by the pressure to act quickly to solve headline-grabbing problems. At the individual 
level, the findings offer evidence that institutional entrepreneurs pursue goals related to the realisation or enhancement of their own interests and values (DiMaggio 1988). They are motivated by a wish to derive value from their transactions with others, to shift power and control to their own group and to impose their own vision for change (DiMaggio 1991). This has led to poor data gathering which in turn has resulted in ineffective policy, wasted public resources and a less effective economy (Curran and Storey 2002). In summary this step indicates that institutional entrepreneurs frame the evidence in support of the policy interest, shaping people's perceptions, cognitions and preferences (Battilana et al. 2009) to gain support from not only other members of the institution but also from stakeholders (Wahid and Sein 2013).

\section{Phase 4: Clearing}

The fourth phase identified in the policy formulation process is the clearing phase. Clearing begins with consultations involving key senior civil servants within the department on draft documents such as government responses to reports, guidance and publicity statements. Officials across government who are involved in the specific policy area must agree on the final documentation before it can be passed to the department's in-house legal team for approval. If the document is to be passed to the media, it must also be cleared by the press office. The department's economists and the Finance Director also need to have a say if financial resources are going to be required to implement the policy. Finally, it must be cleared by the Cabinet Office. Only at this point can the department contact the relevant ministers (e.g. those on a particular Cabinet sub-committee) to seek formal clearance. These key institutional entrepreneurs hold resources along with their social and political skills to lead change, in this phase the change is aligning self-interests with the proposed documentation of enterprise policy (Dacin et al. 2002). Once it has been formally approved by the relevant ministers, the document can be published and made available to the wider civil service, stakeholders, the media and the public. This highlights that institutional theorists have helped to illuminate and frame the legitimacy-building approaches used by new ventures (in this case policy interests), pointing out that organisational structures, procedures and personnel may all be used to build and demonstrate an organisation's acceptability to key constituencies (DiMaggio and Powell 1983). 


\section{Phase 5: Announcements}

The civil servants interviewed in the study were under pressure to prepare policy announcements even if there was no strong objective case for doing so. This involved multiple meetings and brainstorming sessions, the gathering of stakeholders' views and ideas, and attempts to involve as many high profile actors as possible. The announcements to stakeholders and the media were seen as important, as was the choice of minister to make these announcements. This supports Fligstein's (2001) suggestion that only socially skilled institutional entrepreneurs are able to reproduce or contest systems of power and privilege. Skilled institutional entrepreneurs can build up social capital relatively quickly. This social capital enables them to design their institutional arrangements and to negotiate with other institutional entrepreneurs to create a common identity. However, the civil servants argued that the announcements that were made were often superficial and lacking in substance:

There is sometimes a need to announce things which would make departments and ministers look good without any particular evidence or substance announcements first and then details after. An announcement is all well and good and sorting it out afterwards but three months later they want a new announcement (SM:PM9).

The announcement agenda clearly plays a very important role in the formulation of enterprise policy. Civil servants prioritised discussions about press announcements over the need to respond to stakeholder recommendations. The perceived need to make an announcement superseded the requirement to respond fully and realistically to the SME community, and no one questioned whether it would be feasible to deliver what was being promised. The lack of transparency in the enterprise policy formulation process was detrimental to the legitimacy and power of the department. However it is not legitimacy per se that was the important focal point, but the process by which legitimacy was created as an effect of good government - and this is only important if legitimacy then helps to create and stabilise good government (Levi 2005). Precedence was given to making over-hasty announcements rather than creating good government, and in doing so, the main priority of civil servants was the "need to make announcements so that everyone is happy' (JM:PM3). The institutional entrepreneurs, civil servants and the ministerial interest (rather than the minister himself) were the focal point at this phase of the enterprise policy process. This phase focused on the right 'product' to sell, 
make the right announcements, select the right people to sell the product and find the right place to promote it. This phase was clear in pursuing certain interests and acting strategically.

\section{Phase 6: Implementation of the policy or White Paper}

The former Prime Minister Harold Wilson defined a White Paper as "essentially a statement of government policy in such terms that withdrawal or major amendment following consultation or public debate, tends to be regarded as a humiliating withdrawal" (cited in Polsby 2001, p. 11). The final phase of the process involves the department deciding whether delivery of the proposed policy measures is financially feasible (usually established by conducting a cost-benefit analysis) and practical. If the policy measures are feasible, the department begins the implementation process, allocating resources, setting specific objectives and making arrangements for its evaluation and monitoring. However, the lack of formal procedures in the policy formulation process means that there is seldom any evidence that might indicate whether effective implementation is likely to be affordable. Because there was virtually no evidence of any such formal procedures of formulating enterprise policy, the department had its own model of formulating enterprise policy via the six phases' dominant within the data collection. This resonates with institutional theory which insists on the importance of cultural and symbolic dimensions and research on institutional entrepreneurship on the way actors can use intangible resources to impose their institutional projects (Leca et al. 2008). This last phase was primarily dominant for those institutional entrepreneurs who could provide resources and support to undertake the implementation of the enterprise policy initiatives that arose from the process. In this case no enterprise policy initiatives were implemented. Rather announcements were made in accordance to meeting enterprise policy objectives and reports written in ways to address these objectives. The institutional entrepreneurs became embroiled in legitimising the process and ensuring they were upheld as change agents. This meant not forgetting the simple task of ensuring whether these announcements were deliverable, sustainable and feasible.

\section{Conclusion}

The focus of the enterprise policy debate has shifted away from the issues surrounding implementation, monitoring and evaluation to the exploration of why enterprise policy has remained ineffective over the years. An extreme view, offered by notable scholars such as 
Shane (2009) and Storey (2000) is that it is simply 'bad' policy. But this begs the question why the legislative process, which is characterised by widespread consultations and intense scrutiny should produce 'bad' policy which is ineffective. To answer this question the study has taken a step back to open the 'black box' in exploring the formulation of the enterprise policy-making process. A contribution of this study has been the identification of the process in which enterprise policy is formulated through the actions of actors (at both macro and micro-levels). Entrepreneurship research dominantly alludes to institutional entrepreneurs as those who are "autonomous and reflexive agents wreaking havoc on established orders as they created new social entities" (Aldrich 2011, p. 1). This study returns to the 'coalface' of institutions by drawing attention to these institutional entrepreneurs, such as the policymakers and the ministers themselves who are involved in the formulation of enterprise policy (Barley, 2008). Given that entrepreneurship and enterprise policy literature has dominantly focussed on the implementation and evaluation stages (Mole 2002; Xheneti and Kitching 2011; Storey 2002; Bennett 2008), the formulation stage has been largely ignored. An institutional perspective allowed for interpretations into how enterprise policy was formulated and how the actors within such an institution behaved. Given the ineffectiveness of enterprise policies that are created to ensure economic growth it is important that entrepreneurial efforts are to be allocated to productive activities. This study therefore highlights that enterprise policy strategies need to be tailored to the specific institutional context (Wagner and Sterberg 2004) and advocates legitimacy as an endorsement of an organisation by social actors, in which the best way to understand this process was to define its key actors embedded in the formal insitution (Deephouse, 1996).

The process of enterprise policy formulation was documented in detail with the identification of six phases highlighting the importance of institutional entrepreneurs as powerful actors who took an interest in a particular institutional arrangement (policy process). Each phase highlights the causality between policy-making and the inefficient outcomes by explicitly concentrating on factors that do not contribute to achieving enterprise policy aims. As such, considerable time and effort was attributed in legitimising the policy interest. The first phase demonstrates the power of institutional entrepreneurs to impose their policy interests and to dictate how policy is shaped and who is involved thereafter. Civil servants and policy-makers deployed their resources to create and empower arrangements, which suited ministerial, and their own ideologies and policy interests, and within this institutional context they brought about change whilst advancing their own agenda (Battilana et al. 2009). The key role of 
individuals actively engaging in processes of institutional creation, maintenance, disruption, and change via the enterprise policy process (Lawrence et al 2011) showed on-going activity whereby actors reflected on and strategically operated within the institutional context.

Prior research has often studied the characteristics of, and the conditions that produce institutional entrepreneurs, much less prevalent are "detailed descriptions of precisely what it is that institutional entrepreneurs do" (Lawrence and Suddaby 2006, p. 220). Consequently, in line with David et al.'s (2012) study, this paper focuses on a specific kind of institutional entrepreneurship within a specific field context to indicate the importance of the role of institutional entrepreneurs in a specific process of policy-making. Furthermore, the study contributes to the stream of research which has documented the processes whereby actors, individual and collective, affect the institutional contexts within which they work (Lawrence and Suddaby 2006). This study also contributes to the increasing interest in exploring the links between entrepreneurship and institutional phenomena (e.g. Aldrich 2011; Urbano and Alvarez 2013) by using the institutional theoretical lens and also undertaking ethnographic methods of data collection, in particular participant observations which are few and far between limited in the mainstream entrepreneurship journals (Johnstone 2007).

This study captured the mundane, the routine, and the taken-for-granted processes. Participant observation provided depth and nuance to official accounts of policy-making, which has hitherto been unexplored in the entrepreneurship field. Rather than assuming that policy is a linear and stable process as advocated by the 'Green Book' (HM Treasury 2005), the data allowed for an in-depth, accurate and realistic approach to emerge as to how enterprise policy is formulated. The aim of the study was to produce an 'insider' oriented account through the active involvement of the researcher within the organisation (Hammersley and Atkinson 1995) to understand whether this contributed to the ineffectiveness of enterprise policy. The participant observation allowed for rich explorations of the everyday and apparently mundane practices of civil servants and policy-makers, to give a 'bottom-up' account of how enterprise policy is formulated. As this study was based within a formal institution, the behaviour of entrepreneurs was influenced and shaped by the appropriateness and operation of formal institutions (Welter and Smallbone 2011). We brought attention to the ethnographic method for the domain of entrepreneurship, specifically for the policy arena. It holds potential to offer new insights in interpreting and gaining a 
greater understanding of the processes and the actors involved at both the macro and the micro-level in the field of enterprise policy.

This work opens new challenges for future research. First, more evidence is needed to better understand the actors and processes involved in the enterprise policy process. A fundamental gap exists in recognising the role of ministers in the policy-making process, Ministers in particular are key as ministerial interest stems from them and they become part of the process, their importance and influence in policy-making drives the decisions and influences each phase. The civil servants are required to answer to ministers and not the public. A further implication of this study is the need to unravel the Green Book (HM Treasury 2005) in more detail. The assumption that the Green Book (HM Treasury) is a way to 'right all wrongs' is too simplistic and needs to be explored further because the findings show little use of the Green Book (HM Treasury 2005), highlighting intrinsic issues in implementing such guidelines. Some of the enterprise policy-making process phases become generic and require further research which may include longitudinal data collection. For example, the briefing stage can be applied to any policy-making process in any government department in the UK because of the generic nature. This research does not acknowledge the formulation of polices other than enterprise policy as it was not a comparative study. However, this does not rule out that the research can be applied to another sample, either within the same department (with the Coalition government) or with another government department such as health or education to understand whether the findings offered in this study are exclusive to enterprise policy or whether such findings are generalisable to policy-making across UK government departments ${ }^{10}$.

\footnotetext{
${ }^{10}$ Although this paper offers insights into the formulation of enterprise policy-making in only the UK context, similar research could be conducted in other European countries to provide a comparative understanding. Previous studies have highlighted the formulation of enterprise policy-making in different contexts. For example, Hülsbeck and Lehmann (2007) show that Bavarian policy-makers used the advantages and disadvantages of the past when formulating a new entrepreneurship policy. Furthermore, North and Smallbone (2007) undertook a study of various policies encouraging rural entrepreneurship and support for rural enterprise. The authors studied two areas in each of the following countries: Germany, Greece, Poland, Portugal and the UK and undertook interviews with people who were involved in the formulation of these policies. Their findings highlight "marked differences between the five countries in terms of the degree to which they have developed policies for encouraging entrepreneurship and enterprise" and it would appear that the "majority of the examples of successful policy initiatives come from the more developed northern countries" (North and Smallbone 2007, p. 58). Also Stevenson and Lundstrom (2007) describe a typology of the different approaches to enterprise policy adopted by various governments, indicating considerable diversity in the formulation of enterprise policy. For example, in Italy they found that the government formulates targeted entrepreneurship policy around specified groups of the population (known as niche entrepreneurship policy). Given these studies, an assessment of enterprise policy-making at different country levels, at a more in-depth level would provide an interesting extension or replication of this study.
} 
Finally, generalising from this study should be made with caution. First, it was undertaken at a specific point in history. Since then government has changed, individuals have moved to different posts and there is a new Secretary of State and new ministers in charge which will have combined to alter the environment in which the research was undertaken - although enterprise policy has remained ineffective despite the political rhetoric of both the Labour and the Coalition governments in this time (Thompson et al. 2012; Williams 2013). However, this does not preclude the replication of this research with a different sample, either within the same department or with other government departments. Second, the study was limited to one stage of the overall policy process but the intention is to develop future research and explore more fully the other stages of the enterprise policy-making process (for example, engaging with policy influencers or understanding the implementation of enterprise policy at a micro-level). This recognises the bigger picture and understands that different stages of the policy process may also contribute to the ineffectiveness of enterprise policy. This research is therefore only the start in answering Mason's (2009) call for an increased research focus on the effects of government policy-making in the field of entrepreneurship and in understanding why 'bad' enterprise policy exists and how to address the critics concerns of ineffectiveness of such a policy. 


\section{References}

Acs, Z. J., Morck, R., Shaver, J. M. \& Yeung, B. (1997). The Internationalization of Small and Medium-Sized Enterprises: A Policy Perspective. Small Business Economics, 9(1), 7-2.

Aldrich, H. E. (2011). Heroes, Villains, and Fools: Institutional Entrepreneurship, Not Institutional Entrepreneurs. Entrepreneurship Research Journal, 1(2), 1-6.

Aldrich, E. H. \& Fiol, M. C. (1994). Fools rush in? The institutional context of industry creation. Academy of Management. The Academy of Management Review, 19(4), 645-670.

Audretsch, D. B. (2004). Sustaining innovation and growth: public policy support for entrepreneurship. Industry \& Innovation, 11(3), 167-191.

Audretsch, D. B. \& Beckmann, I. A. M. (2007). From small business to entrepreneurship policy. In D. B. Audretsch, I. Grilo \& A. R.Thurik (Eds.) Handbook of Research on Entrepreneurship Policy. Great Britain: Edward Elgar, pp. 36-53.

Bannock, G. (2005). The Economics and Management of Small Business. New York: Routledge.

Barley, S. R. (2008). Coalface Institutionalism. In R. Greenwood, C. Oliver, K. SahlinAndersson \& R. Suddaby (Eds.) The Sage Handbook of Organizational Institutionalism. London: Sage Publications, pp. 490-515.

Battilana, J. (2006). Agency and Institutions: The Enabling Role of Individuals' Social Position. Organization, 13(5), 653-676.

Battilana, J., Leca, B. \& Boxenbaum, E. (2009). How Actors Change Institutions: Towards a Theory of Institutional Entrepreneurship. The Academy of Management Annals, 3(1), 65-107.

Bayard de Volo, L. \& Schatz, E. (2004). From the Inside Out: Ethnographic Methods in Political Research. Political Science and Politics, 37, 267-271. 
Baumol, W. J. (1990). Entrepreneurship: poductive, unproductive and destructive. Journal of Political Economy, 98(5), 893-921.

Beckert, J. (1999). Agency, entrepreneurs, and institutional change. The role of strategic choice and institutionalized practices. Organization Studies, 20(5), 777-799.

Bennett, R. (2008). SME support policy in Britain since the 1990s: what have we learnt? Environment and Planning C: Government and Policy, 17(5), 375-97.

BERR. (2008). Enterprise: Unlocking the UK's Talent. Report for HM Treasury, London.

Bevir, M. \& Rhodes, R. A.W. (2003). Interpreting British Governance. London: Routledge.

Bitektine, A. (2011). Toward a Theory of Social Judgments of Organizations: The Case of Legitimacy, Reputation, and Status. The Academy of Management Review, 36(1), 151-179.

Blackburn, R. \& Smallbone, D. (2008). Researching small firms and entrepreneurship in the UK: developments and distinctiveness. Entrepreneurship Theory and Practice, 32(2), 267288.

Blackburn, R. \& Smallbone, D. (2011). Policy support for SMEs. Environment and Planning C: Government and Policy, 29(4), 571-576.

Bolton, J.E. (1971). Report of the Committee of Enquiry on small firms. Bolton Report Cmnd. 4811. London: HMSO.

Brewer, J. D. (2000). Ethnography. Buckingham: Open University Press.

Bridge, S. (2010). Rethinking Enterprise Policy: can failure trigger new understanding? Basingstoke: Palgrave Macmillan.

Bruton, G. D., Ahlstrom, D., \& Han-Lin, L. (2010). Institutional Theory and Entrepreneurship: Where Are We Now and Where Do We Need to Move in the Future? Entrepreneurship Theory and Practice, 34(3), 421-440. 
Bullock, H., Mountford, J. \& Stanley, R. (2001). Better Policy-Making. Report, Centre for Mangement and Policy Studies.

Burton, P. (2006). Modernising the policy process: Making policy research more significant? Policy Studies, 27(3), 173-195.

Cabinet Office. (1999). Modernising Government. Report no. Cm 4310. London: The Stationery Office.

Campbell, N. D. (2012) Entrepreneurial action and the rules of the game. Journal of Entrepreneurship and Public Policy, 1(1), 4-11.

Centre for Cities. (2013). Support for growing businesses: A policy briefing. Available at: http://www.centreforcities.org/research/2013/04/23/support-for-growing-businesses/ (accessed 12 May 2013).

Cornett, A. P. (2009). Aims and strategies in regional innovation and growth policy: A Danish perspective. Entrepreneurship \& Regional Development, 21(4), 399-420.

Cowie, P. (2012). SME Policy Evaluation: Current Issues and Future Chaleenges. In R. A. Blackburn \& M. T. Schaper (Eds.) Government, SMES and Entrepreneurship Development: Policy, Practice and Challenges. Surrey: Gower Publishing, pp. 243-257.

Curran, J. \& Storey, D. J. (2002). Small business policy in the United Kingdom: The inheritance of the Small Business Service and implications for its future effectiveness. Environment and Planning C: Government and Policy, 20(2), 163-177.

Dacin, T., Goodstein, J. \& Scott, W. R. (2002). Institutional theory and institutional change: Introduction to the special research forum. The Academy of Management Journal 43(4): 4557.

David, R. J., Sine, W. D. \& Haveman, H. A. (2012). New Organizational Forms in Emerging Fields. Organization Science, Papers in Advance, 1-22. 
Deephouse, D. L. (1996). Does Isomorphism Legitimate? The Academy of Management Journal, 39(4), 1024-1039.

Delbridge, R. \& Edwards, T. (2007). Reflections on developments in institutional theory: Toward a relational approach. Scandanavian Journal of Management, 23(2), 191-205.

Delmar, F. \& Shane, S. (2004). Legitimating First: Organizing Activities and the Survival of New Ventures. Journal of Business Venturing, 19(3), 385-410.

Denzin, N. K. (1978). The research act: A theoretical introduction to sociological methods ( $2^{\text {nd }}$ ed.). New York: McGraw-Hill.

Department for Business, Innovation \& Skills. (2012). Understanding the Enterprise Finance Guarantee. Available at: https://www.gov.uk/understanding-the-enterprise-finance-guarantee (accessed 10 January 2013).

DiMaggio, P. J. (1991). Constructing an organizational field as a professional project: U.S. art museums, 1920-1940. In W. P. Powell \& P. J. DiMaggio (Eds.) The New Institutionalism in Organizational Analysis. Chicago: University of Chicago Press, pp. 267-292.

DiMaggio, P. J. (1988). Interest and agency in institutional theory. In L. G. Zucker (Ed.) Institutional Patterns and Organizations. Cambridge, MA: Ballinger, pp. 3-22).

DiMaggio, P. J. \& Powell, W. W. (1983). The iron cage revisited: Institutional isomorphism and collective rationality in organizational fields. American Sociological Review, 48(2), 147160.

Easton, D. (1965). A Systems Analysis of Political Life. New York:Wiley.

Eisenhardt, K. M. \& Graebner, M. E. (2007). Theory building from cases: Opportunities and challenges. The Academy of Management Journal, 50(1), 25-32.

Ekanem, I. \& Smallbone, D. (2007). Learning in Small Manufacturing Firms. International Small Business Journal, 25(2),107-129. 
Emerson, R. M., Fretz, R. I. \& Shaw, L. L. (1995). Writing Participant observation Fieldnotes. Chicago: University Press of Chicago.

Fetterman, D. M. (2010). Ethnography: Step by Step. Thousand Oaks: CA Sage Publications.

Fine, G. A., Morrill, C. \& Surianarain, S. (2010). Ethnography in Organizational Settings. In D. Buchanan \& A. E. Bryman(Eds.) The Sage Handbook of Organizational Research Methods London: Sage Publications, pp. 602-670.

Fischer, F., Miller, G. \& Sidney, M. (2006). Handbook of Public Policy Analysis: Theory, Politics and Methods. England: CRC.

Fisher, S. (2012). Policy storylines in Indian climate politics: opening new political spaces? Environment and Planning C: Government and Policy, 30(1), 109-127.

Fligstein, N. (1997). Social skill and institutional theory. The American Behavioral Scientist, 40(4), 397-405.

Fligstein, N. (2001). Social Skill and the Theory of Fields. Sociological Theory, 19(2), 105125.

Garud, R., Hardy, C. \& Maguire, S. (2007). Institutional Entrepreneurship as Embedded Agency: An Introduction to the Special Issue. Organization Studies, 28(7), 957-969.

Gibb, A. A. (2000). SME policy, academic research and the growth of ignorance, mythical concepts, myths, assumptions, rituals and confusions. International Small Business Journal, $18(3), 13-35$.

Gilbert, B., Audretsch, D. B. \& McDougall, P. P. (2004). The Emergence of Entrepreneurship Policy. Small Business Economics, 22(3/4), 313-323.

Greene, F. J. (2009). Assessing the impact of policy interventions: the influence of evaluation methodology. Environment and Planning C: Government and Policy, 27(2), 216-229. 
Greene, F. J., Mole, K. F. \& Storey, D. J. (2008). Three Decades of Enterprise Culture: Entrepreneurship, Economic Regenration and Public Policy. Basingstoke: Palgrave MacMillan.

Greenwood, R., Raynard, M., Kodeih, F., Micelotta, E. R. \& Lounsbury, M. (2011) Institutional complexity and organizational responses. Academy of Management Annals, 5(1), $317-371$.

Grimm, H. (2006). Entrepreneurship Policy and Regional Economic Growth: Exploring the Link and Theoretical Implications. In B. Rihoux \& H. Grimm (Eds.) Innovative Comparative. Methods for Policy Analysis Beyond the Quantitative-Qualitative Divide USA: Springer.

Guba, E. G. \& Lincoln, Y. S. (1981). Effective evaluation: Improving the usefulness of evaluation results through responsive and naturalistic approaches. San Francisco: JosseyBass.

Guba, E. G. \& Lincoln, Y. S. (2005). "Paradigmatic controversies, contradictions, and emerging influences" In N. K. Denzin \& Y. S. Lincoln (Eds.), The Sage Handbook of Qualitative Research (3rd ed.). Thousand Oaks, CA: Sage, pp. 191-215.

Hammersley, M. \& Atkinson, P. (1995). Ethnography: Principles in Practice. London: Routledge.

HM Treasury. (2005). The Green Book-Appraisal and Evaluation in Central Government. London: The Stationery Office.

Hewitt-Dundas, N. \& Roper, S. (2011). Creating advantage in peripheral regions: The role of publicly funded R\&D centres. Research Policy, 40(6), 832-841.

Hirsch, P. M. \& Lounsbury. M. (1997). Ending the Family Quarrel: Toward a Reconciliation of "Old" and "New" Institutionalisms. American Behavioral Scientist, 40, 406-418. 
Huggins. R, \& Williams, N. (2009). Enterprise and public policy: a review of Labour government intervention in the United Kingdom. Environment and Planning C: Government and Policy, 27(1), 19-41.

Hülsbeck, M. \& Lehmann, E.E. (2007). Entrepreneurship Policy in Bavaria: Between Laptop and Lederhosen. In D. B. Audretsch, I. Grilo \& A. R.Thurik (Eds.) Handbook of Research on Entrepreneurship Policy. Great Britain: Edward Elgar, pp. 200-212.

Jennings, P. D., Greenwood, R., Lounsbury, M. D. \& Suddaby, R. (2013). Institutions, entrepreneurs, and communities: A special issue on entrepreneurship. Journal of Business Venturing, 28(1), 1-9.

Johnstone, B. A. (2007). Ethnographic methods in entrepreneurship research. In H. Neergaard \& J. P. Ulhoi (Eds.), Handbook of Qualitative Research Methods in Entrepreneurship. Cheltenham: Edward Elgar, pp. 97-121.

Jones, P., Beynon, M., Pickernell, D. \& Packham, G. (2013). Evaluating the impact of different training methods on SME business performance. Environment and Planning $C$ : Government and Policy, 31(1), 56-81.

Karlsson, C. \& Andersson, M. (2009). Entrepreneurship Policies: Principles, Problems and Opportunities. In J. Leitao \& R. Baptista (Eds.) Public Policies for Fostering Entrepreneurship. Dordrecht: Springer, pp. 111-131.

King, N. (2004). Using templates in the thematic analysis of text. In C. Cassell \& G. Symon (eds.) Essential Guide to Qualitative Methods in Organizational Research. London: Sage Publications, pp. 256-70.

Kingdon, J. (1984). Agendas, Alternatives and Public Policy. Boston: Little Brown.

Lambrecht, J. \& Pirnay, F. (2005). An evaluation of public support for private external consultancies to SMEs in the Walloon Region of Belgium. Entrepreneurship \& Regional Development, 7(2), 89-108. 
Lawrence, T. B., Suddaby, R. \& Leca, B. (2011). Institutional Work: Refocusing Institutional Studies of Organization. Journal of Management Inquiry, 20(1), 52-58.

Lawrence, T. B. \& Suddaby, R. (2006). Institutions and institutional work. In S. Clegg, C. Hardy, T. Lawrence \& W. Nord (Eds.) The Sage Handbook of Organizational Studies. London: Sage, pp. 215 - 254.

Leca, B., Battilana, J. \& Boxenbaum, E. (2008). Agency and Institutions: A Review of Institutional Entrepreneurship. Harvard Business School Working Knowledge (working paper number: 08-096).

LeCompte, M. D. \& Schensul, J. J. (1999). Designing and conducting ethnographic research. Walnut Creek, CA: AltaMira Press.

Lenihan, H. (2011). Enterprise policy evaluation: Is there a 'new' way of doing it? Evaluation and Program Planning, 34, 323-332.

Levi, M. (2005). Achieving Good Government - And, Maybe, Legitimacy. Paper presented at the New Frontiers of Social Policy. Arusha, Tanzania.

Levy, D. \& Scully, M. (2007). The institutional entrepreneur as a modern prince: the strategic face of power in contested fields. Organizational Studies, 28(7), 1-21.

Linder, S. H. \& Peters, B.G. (1990). An Institutional Approach to the Theory of PolicyMaking: The Role of Guidance Mechanisms in Policy Formulation. Journal of Theoretical Politics, 2(1), 59-83.

Lounsbury, M. \& Crumley, E. T. (2007). New practice Creation: An Institutional Perspective on Innovation. Organization Studies, 28(7), 993-1012.

Lukes, S. (1974). Power: A Radical View. London: Macmillan.

Lundstrom, A. \& Stevenson, L. (2005). Entrepreneurship Policy: Theory and Practices. New York: Springer. 
Maguire, S., Hardy, C. \& Lawrence, T. B. (2004). Institutional entrepreneurship in emerging fields: HIV/AIDS treatment advocacy in Canada. The Academy of Management Journal, 47(5), 567-679.

March, J. G. \& Olsen, J. P. (1984). The new institutionalism: Organisational factors in political life. American Political Science Review, 78(2), 734-749.

Marshall, C. \& Rossman, G. B. (2006). Designing Qualitative Research. Thousand Oaks, CA: Sage Publications.

Mason, C. (2009). Policy as a focus for small business research. Envronement and Planning C: Government and Policy, 27(2), 191-194.

Mason, C. \& Brown, R. (2013). Creating good public policy to support high-growth firms. Small Business Economics, 40(2), 211-225.

Mason, C. \& Rogers. A. (1997). The Business Angel's Investment Decision: An Exploratory Analysis. In D. Deakins, P. Jennings \& C. Mason. (Eds.) Small Firms Entrepreneurship in the Nineties. London: Paul Chapman, Publishing, pp. 29-46.

McGaughey, S. (2012). Institutional entrepreneurship in North American lighting protection standards: Rhetorical history and unintended consequences of failure. Business History, 55(1),73-97.

Meyer, J. W. \& Rowan, B. (1977). Institutionalized organizations: Formal structure as myth and ceremony. American Journal of Sociology, 83(2), 340-363.

Mole, K. (2002). Business Advisers' Impact on SMEs: An Agency Theory Approach. International Small Business Journal, 20(2), 139-162.

Mole, K., Hart, M., Roper, S. \& Saal, D. (2011). Broader or deeper? Exploring the most effective intervention profile for public small business support. Environment and Planning A, 43(1), 87-105. 
Mutch, A. (2007). Reflexivity and the Institutional Entrepreneur: A Historical Exploration. Organization Studies, 28(7), 1123-1140.

North, D. (1990). Institutions, Institutional Change and Economic Performance. Cambridge: Cambridge University Press.

North, D. \& Smallbone, D. (2006). Developing entrepreneurship and enterprise in Europe's peripheral rural areas: Some issues facing policy-makers. European Planning Studies, 14(1), 41-60.

North, D., Smallbone, D. \& Vickers, I. (2001). Public sector support for innovating SMEs. Small Business Economics, 16(4), 303-317.

Oborn, E., Barrett, M. \& Dawson, S. (2013). Distributed Leadership in Policy Formulation: A Social Material Perspective. Organization Studies 34(2): 253-276.

Oliver, C. (1991). Strategic Responses to Institutional Processes. The Academy of Management Review, 16(1), 145-179.

Pacheco, D. F., York, J. G., Dean, T. J, \&Sarasvathy, S. D. (2010). The Coevolution of Institutional Entrepreneurship: A Tale of Two Theories. Journal of Management 36(4): 9741010.

Parsons, W. (1995). Public Policy: An Introduction to the Theory and Practice of Policy Analysis. Cheltenham: Edward Elgar.

Patton, M. Q. (2002). Qualitative Research and Evaluation Methods (3 ${ }^{\text {rd }}$ ed). London: Sage Publications.

Peters, B. G. (2000), Institutional Theory: Problems and Prospects. Report, Institute for Advanced Studies, Vienna.

Polsby, N. W. (2001). Legitimacy in British policy-making: functional alternatives to the civil service. British Journal of Politics and International Relations, 3(1), 5-35. 
Pratt, M. G. (2009). For the lack of boilerplate: Tips on writing up (and reviewing) qualitative research. The Academy of Management Journal, 52(5), 856-865.

Ram, M. \& Trehan, K. (2010). Critical action learning, policy learning and small firms: An inquiry. Management Learning, 41(4), 415-428.

Rao, H., Morrill, C. \& Zald, M. N. (2000). Power plays: How social movements and collective action create new organizational forms. Research in Organizational Behaviour, 22, 239-282.

Richard, D., Connell, D., Ibbetson, P., Kestenbaum, J. \& Richards, A. (2007). Richard review on small business and government: interim report. Conservative Party, March.

Sapru, R. K. (2010). Public Policy: Art and Craft of Policy Analysis. London: Prentice-Hall Publishing.

Scott, W. R. (2001). Institutions and Organizations. Thousand Oaks, CA: Sage Publications.

Scott, W. R. (2004). Institutional Theory: Contributing to a Theoretical Research Program. In K. G. Smith \& M. A. Hitt (Eds.) Great Minds in Management: The Process of Theory Development. Oxford: Oxford University Press.

Selznick, P. (1949). TVA and the Grass Roots. Berkley CA: University of California Press.

Shane, S. A. (2008). The Illusions of Entrepreneurship; The costly myths that entrepreneurs, investors and policy makers live by. New Haven: Yale University Press.

Shane, S. (2009). Why encouraging more people to become entrepreneurs is bad public policy. Small Business Economics, 33(2), 141-149.

Smallbone, D. \& Welter, F. (2010). Entrepreneurship and government policy in former Soviet republics: Belarus and Estonia compared. Environment and Planning C: Government and Policy, 28(2), 195-210. 
Sobel, R. (2008). Testing Baumol: instutional quality and the productivity of entrepenreuship. Journal of Business Venturing, 23(6), 641-655.

Sotarauta, M. \& Pulkkinen, R. (2011). Institutional entrepreneurship for knowledge regions: in search of a fresh set of questions for regional innovation studies. Environment and Planning C: Government and Policy, 29(1), 96-112.

Stenholm, P., Acs, Z. J. \& Wuebker, R. (2013). Exploring country-level institutional arrangements on the rate and type of entrepreneurial activity. Journal of Business Venturing, 28(1), 176-193.

Stevenson, L. \& Lundstrom, A. (2007). Dressing the emperor: The fabric of entrepreneurship policy. In D. B. Audretsch, I. Grilo \& A. R. Thurik (Eds.), Handbook of Research on Entrepreneurship Policy). Great Britain: Edward Elgar, pp. 94-129.

Storey, D. J. (2000). Six Steps to Heaven: Evaluating the Impact of Public Policies to Support Small Business in Developed Economies. In L. Sexton \& H. Landstrom (Eds.) The Blackwell Handbook of Entrepreneurship. Great Britain: Blackwell Publishers Ltd, pp. 176-194.

Storey, D. J. (2000) Understanding the Small Business Sector. UK: Thomson.

Storey, D. J. (2000). Six Steps to Heaven: Evaluating the Impact of Public Policies to Support Small Business Developed Economies. In L. Sexton \& H. Landstrom (Eds.), The Blackwell Handbook of Entrepreneurship. Great Britain Blackwell Publishers Ltd, pp. 176-194.

Storey, D. J. (2002). Methods evaluating the impact of public policies to support small businesses: The six steps to heaven. International Journal of Entrepreneurship Education, $1(1), 181-202$.

Streeck, W. \& Thelen, K. (2005). Introduction: institutional change in advanced political economies. In W. Streeck \& K. Thelen (Eds.) Beyond Continuity: Institutional Change in Advanced Political Economies. Oxford: Oxford University Press, pp. 1-39. 
Suchman, M. C. (1995). Managing Legitimacy: Strategic and Institutional Approaches. The Academy of Management Review, 20(3), 571-610.

Suddaby, R. (2010). Challenges for Institutional Theory. Journal of Management Inquiry, 19(1), 14-20.

Thompson, J., Scott, J. \& Downing, R. (2012). Enterprise policy, delivery, practice and research: largely rhetoric or under-valued achievement? International Journal of Public Sector Management, 25(5), 332-345.

Urbano, D. \& Alvarez, C. (2013). Institutional dimensions and entrepreneurial activity: an international study. Small Business Economics, DOI: 10.1007/s11187-013.9523-7.

Van Cauwenberge P., Vander Bauwhede, H. \& Schoonjans, B. (2013). An evaluation of public spending: the effectiveness of a government-supported networking program in Flanders. Environment and Planning C: Government and Policy, 31(1), 24-38.

Van Praag, C. M. \& Versloot, P. H. (2007). What is the value of Entrepreneurship? A Review of Recent Research. Small Business Economics, 29(4), 351-382.

Van Stel, A., Storey, D. J. \& Thurik, A. (2007). The Effect of Business Regulations on Nascent and Young Business Entrepreneurship. Small Business Economics, 28(2), 171-186.

Vega, A., Chiasson, M. \& Brown, D. (2013). Understanding the causes of informal and formal discretion in the delivery of enterprise policies: a multiple case study. Environment and Planning C: Government and Policy, 31(1), 102-118.

Vishanth, W., Yogesh, K. D. \& Zahir, I. (2009). The diffusion and use of institutional theory: a cross-disciplinary longitudinal literature survey. Journal of Information Technology, 24, 354-368.

Wagner, J. \& Sternberg, R. (2004). Start-up activities, individual characteristics, and the regional milieu: Lessons for entrepreneurship support policies from German micro data. The Annals of Regional Science, 38(2), 219-240. 
Wahid, F. \& Sein, M. K. (2013). Institutional entrepreneurs: The driving force in institutionalization of public systems in developing countries. Transforming Government: People, Process and Policy, 7(1), 76-92.

Waller, P., Morris, R. M. \& Simpson, D. (2008). Understanding the Formulation and Development of Government Policy in the Context of FOI. Report, The Constitution Unit.

Weik, E. (2011). Institutional Entrepreneurship and Agency. Journal for the Theory of Social Behaviour, 41(4), 466-481.

Welter, F. (2011). Book review: Rethinking enterprise policy: Can failure trigger a new understanding? International Small Business Journal, 29(6),733-744.

Williams, N. (2013). Entrepreneurship and the role of policy. Environment and Planning C: Government and Policy. 31(1), 1-4.

Wren, C. \& Storey, D. J. (2002). Evaluating the effect of soft business support upon small firm performance. Oxford Economics Papers, 54(2), 334-365.

Xheneti, M. \& Kitching, J. (2011). From discourse to implementation: enterprise policy development in postcommunist Albania. Environment and Planning C: Government and Policy, 29(6), 1018-103.

Young Lord. (2013). Growing Your Business: A Report on Growing Micro Businesses. Report, URN BIS/13/729. 